\title{
Pengaruh Promosi Pendidikan Terhadap Minat Peserta Didik Baru MAN 3 Banyuwangi
}

\author{
Mahbub $^{1}$, Eva Husnia Zen ${ }^{2}$ \\ e-mail: mahbubnawawi08@gmail.com ${ }^{1,}$ evahusniazen@gmail.com ${ }^{2}$ \\ Prodi Manajemen Pendidikan Islam \\ Institut Agama Islam Darussalam Blokagung Banyuwangi
}

\begin{abstract}
This research is directed to 4 points, such as (1) how is education marketing pass promotion strategy in MAN 3 Banyuwangi 2018/2019 academic year? (2) how is Man 3 Banyuwnagi new student's interes 2018/2019 academic year (3) is there some afefect an education marketing pass promotion strategy towards MAN 3 Banyuwangi new student's interest 2018/2019 academic year? (40 How big of an effecting education marketing pass promotion staretgy towards new student's 2018/2019 academic year?.The type of this research was descriptif quantitative with the method product moment on the data validity test and for searching data reliability using alpha formula. Arter analyzing the data wich is collected, found that (10 education marketing pass promotion strategy in Man 3 Banyuwangi 2018/2019 academic year was good (2) Man 3 Banyuwangi new student's interest 2018/2019 academic year was strong (3) there is an affect of education marketing pass prmotion strategy towards MAN 3 Banyuwangi new student's interest 2018/2019 academic year (40 the affect of education marketing pass promotion strategy towards new students' interest 2018/2019 academic year of Man 3 Banyuwangi is 53,5\%.
\end{abstract}

Keywords : Promotion, Student's Interest

\begin{abstract}
Abstrak
Penelitian ini diarahkan pada 4 hal pokok, yaitu (1) Bagaimana marketing pendidikan melalui strategi promosi MAN 3 Banyuwangi tahun pembelajaran 2018/2019? (2) Bagaimana minat peserta didik baru MAN 3 Banyuwangi tahun pembelajaran 2018/2019? (3) Adakah pengaruh marketing pendidikan melalui strategi promosi terhadap minat peserta didik baru MAN 3 Banyuwangi tahun pembelajaran 2018/2019? (4) Seberapa besar pengaruh marketing pendidikan melalui strategi promosi terhadap minat peserta didik baru MAN 3 Banyuwangi tahun pembelajaran 2018/2019?. Penelitian ini menggunakan metode deskriptif kuantitatif dengan teknik product moment pada uji validitas data dan untuk mencari reliabilitas data menggunakan rumus alpha. Setelah melakukan analisis data yang dikumpulkan, ditemukan bahwa (1) marketing pendidikan melalui strategi promosi MAN 3 Banyuwangi tahun pembelajaran 2018/2019 baik. (2) Minat peserta didik baru MAN 3 Banyuwangi tahun pembelajaran 2018/2019 kuat (3) Ada pengaruh marketing pendidikan melalui strategi promosi terhadap minat peserta didik baru MAN 3 Banyuwangi tahun pembelajaran 2018/2019 (4) pengaruh marketing pendidikan melalui strategi promosi terhadap minat peserta didik baru MAN 3 Banyuwangi tahun pembelajaran 2018 sebesar 53,5\%.
\end{abstract}

Kata Kunci: Promosi, Minat Peserta Didik

Pengaruh Promosi Pendidikan Terhadap Minat Peserta Didik Baru MAN 3

Banyuwangi

Mahbub, Eva Husnia Zen 


\section{A. Pendahuluan}

1. Latar Belakang

Dalam proses mencerdaskan kehidupan bangsa yang tertuang dalam butir pembukaan Undang-Undang 1945, Indonesia sendiri telah menggalakkan program wajib belajar 12 tahun serta memberikan fasilitas sekolah gratis mulai dari tingkat pendidikan terendah seperti SD/MI hingga Sekolah Lanjut Tingkat Atas (SLTA) seperti MA/SMA sebagai salah satu bentuk perealisasian pembukaan undang-undang itu sendiri. Namun, dalam ranah era globalisasi dengan persaingan diseluruh sendinya, tentu memberikan nilai terhadap berbagai sistem maupun aspek penunjang proses belajar mengajar bahwa unsur tersebut saja belum dipandang cukup dalam penyelenggaraan proses pendidikan sehingga peningkatan kualitas mutu merupakan suatu standar tolok ukur serta sebuah keniscayaan dalam meningkatkan derajat, taraf kecakapan, dan kepandaian serta daya saing sumber daya manusia yang menjadi sasaran utama dalam pendidikan sehingga mampu bersaing dalam dunia nasional maupun internasional.

Sesuai dengan Undang-Undang No. 20 Tahun 2003 pasal 45 tentang Sistem Pendidikan Nasional, mengenai peningkatan mutu serta relevansi dan efisiensi manajemen pendidikan untuk menghadapi tantangan sesuai dengan tuntutan perubahan kehidupan lokal dimana hal tersebut berdampak besar bagi kualitas pendidikan sehingga peningkatan derajat taraf kecakapan dan kepandaian, maupun kualitas sumber daya manusia dapat meningkat.

Dalam berbagai keuntungannnya, mutu merupakan dimensi yang memiliki andil cukup besar serta signifikan dalam berbagai sudut pandang, diantaranya merupakan pembangun reputasi dan citra positif, sampai menumbuhkan kepercayaan konsumen, sehingga menimbulkan ketertarikan dan sikap yang berkesinambungan dengan begitu instansi penyelenggara edukasi seperti sekolah dapat bertahan dalam kompetisi global serta menunjukkan eksistensinya. Salah satu bukti eksistensi dalam suatu lembaga pendidikan, ditandai dengan meningkatnya minat peserta 
didik dalam menetukan pilihan terhadap lembaga tersebut. Peserta didik merupakan salah satu komponen utama dalam proses belajar mengajar, oleh karenanya, perkembangan jumlah peserta didik merupakan indikator dan tujuan disetiap lembaga pendidikan yang dapat diupayakan melalui berbagai hal diantaranya adalah peningkatan pelayanan pendidikan yang dapat dicapai dengan strategi marketing pendidikan.

Dilihat dari adanya persaingan antar lembaga pendidikan maka diperlukan adanya strategi marketing pendidikan melalui promosi yang dipandang sebagai suatu komunikasi di bidang pemasaran yang juga tidak hanya berfokus pada memperkenalkan produk, tapi juga memenuhi kebutuhan konsumen sehingga kepuasan dapat diraih. Seperti yang diungkapkan oleh Tjiptono (dalam Dewi 2014:53) kepuasan pelanggan (konsumen) adalah tingkat perasaan seseorang setelah membandingkan kinerja (hasil) yang dia rasakan dengan harapannya. Promosi sendiri oleh Buchari Alma (2002:179) diartikan sebagai sejenis komunikasi yang memberi penjelasan yang meyakinkan calon konsumen tentang barang dan jasa yang bertujuan untuk memperoleh perhatian, mendididk, mengingatkan, dan meyakinkan calon konsumen. Sesuai dengan yang diungkapkan oleh Kotler (2005:22) bahwa terdapat sebuah revolusi dari konsep pemasaran yakni pekerjaan pemasaran bukanlah suatu pekerjaan untuk menemukan pelanggan yang tepat bagi suatu produk, namun menemukan produk yang tepat bagi pelanggan. Oleh karenanya, promosi merupakan variabel tepat yang dapat diaplikasikan dalam memasarkan serta mensosialisasikan suatu lembaga pendidikan sehingga dapat diterima.

Madrasah Aliyah Negeri 3 Banyuwangi merupakan salah satu Sekolah Lanjutan Tingkat Atas (SLTA) yang berada di Kecamatan Srono. Madrasah Aliyah Negeri 3 Banyuwangi termasuk kategori sekolah favorit dan sekolah dengan tata kelola yang sangat rapi. Terbukti dari sistem pengajaran, fasilitas, ekstrakulikuler dan kurikulum terbaik yang diberikan oleh sekolah ini menjadikannya sebagai akreditasi terbaik tingkat SLTA se Jawa Timur. 
Dengan penjelasan yang telah dipaparkan di atas, yang mengantarkan pada suatu kesimpulan bahwa sebuah lembaga pendidikan tentulah memiliki sebuah strategi marketing melalui promosi yang tepat agar dapat mempertahankan eksistensinya ditengah sengitnya sebuah persaingan disamping itu juga agar mengetahui strategi dalam perekrutan dan meningkatkan minat calon peserta didik.

2. Rumusan Masalah

1) Bagaimana marketing pendidikan melalui strategi promosi pendiikan MAN 3 Banyuwangi?

2) Bagaimana minat peserta didik baru MAN 3 Banyuwangi?

3) Adakah pengaruh marketing pendidikan melalui strategi promosi pendidikan terhadap minat peserta didik baru MAN 3 Banyuwangi?

4) Seberapa besar pengaruh marketing pendidikan melalui strategi promosi pendidikan terhadap minat peserta didik baru MAN 3 Banyuwangi?

3. Tujuan Masalah

1) Untuk mengetahui marketing pendidikan melalui strategi promosi pendidikan MAN 3 Banyuwangi.

2) Untuk mengetahui minat peserta didik baru MAN 3 Banyuwangi.

3) Untuk mengetahui adakah pengaruh marketing pendidikan melalui strategi promosi pendidikan terhadap minat peserta didik baru MAN 3 Banyuwangi.

4) Untuk mengetahui seberapa besar pengaruh marketing pendidikan melalui strategi promosi pendidikan terhadap minat peserta didik baru MAN 3 Banyuwangi.

4. Manfaat Penelitian

1) Secara teoritis:

a. Untuk mengembangkan ilmu pengetahuan khususnya dalam bidang implementasi marketing pendidikan melalui strategi promosi.

b. Untuk memperkuat teori bahwa strategi marketing melalui kegiatan promosi sangatlah penting. 
2) Secara praktis:

1. Peneliti

Sebagai ilmu tambahan dan pembelajaran.

2. Lembaga yang diteliti

Sebagai masukan bagi perkembangan strategi marketing

3. Peneliti selanjutnya

Dapat digunakan untuk kajian, rujukan, referensi, dan paparan acuan.

4. Masyarakat umum

Sebagai bahan pengetahuan dalam penyusunan karya ilmiah, dan sumbangan pemikiran terkait strategi marketing pendidikan melalui srategi promosi.

\section{B. Landasan Teori}

1. Promosi Pendidikan

a. Pengertian Promosi Pendidikan

Menurut Buchari Alma dan Ratih Huriyati (dalam Pratiwi, 2017:15) promosi adalah suatu bentuk komunikasi pemasaran yang merupakan aktivitas pemasaran yang berusaha menyebarkan informasi, mempengaruhi/membujuk, mengingatkan pasar sasaran atas perusahaan dan produknya agar bersedia menerima,membeli dan loyal pada produk yang ditawarkan perusahaan yang bersangkutan.

Herdiana dalam bukunya Manajemen Strategi Pemasaran (2015:156) promosi adalah suatu bauran pemasaran yang digunakan untuk meningkatkan nilai pelanggan atau membangun ekuitas merek dalam ingatan pelanggan.

Menurut Saladin, (1991:66) promosi merupakan suatu komunikasi informasi penjual dan pembeli yang bertujuan untuk merubah sikap dan tingkah laku pembeli, yang sebelumnya tidak mengenal menjadi mengenal sehingga menjadi pembeli dan tetap mengingat produk tersebut. 
Amalia (2017:3) startegi promosi yang dimaksud disini adalah setiap langkah yang diambil oleh sekolah untuk berkomunikasi dengan masyarakat dengan tujuan dapat mencapai target atau sasaran yang sudah ditetapkan sekolah.

Sehingga dapat ditarik kesimpulan bahwa promosi dalam ranah pendidikan adalah bentuk kegiatan komunikasi pemasran yang dilakukan oleh satuan pendidikan tertentu dengan tujuan meningkatkan nilai pelanggan, menginformasikan, mempengaruhi, dan meningkatkan capaian yang telah ditetapkan, dan merubah sikap dan tingkah laku pembeli.

b. Tujuan Promosi

Shinta dalam Manajemen Pemasaran (2011:121) tujuan utama promosi adalah untuk menginformasikan, mempengaruhi dan membujuk serta mengingatkan pelanggan sasaran tentang perusahaan dan bauran pemasarannya.

Sedangkan menurut Hari dalam skripsinya Pengaruh Promosi terhadap Pendaftar Calon Siswa Baru (2007:17-18) promosi memiliki 4 tujuan yaitu:

1) Membujuk

Promosi yang bersifat membujuk ini diarahkan untuk mendorong pembelian dan dimaksudkan agar dapat memberi pengaruh dalam waktu yang lama terhadap perilaku pembeli. Promosi yang bersifat persuasif ini akan menjadi dominan jika produk yang bersangkutan mulai memasuki tahap pertumbuhan di dalam siklus kehidupannya.

2) Mengingatkan

Promosi yang bersifat mengingatkan dilakukan terutama untuk mempertahankan merk produk di hati masyarakat dan perlu dilakukan selama tahap kedewasaan didalam siklus kehidupan produk.

3) Memberi tahu 
Kegiatan promosi ini dapat ditujukan untuk memberitahu pasar yang dituju tentang penawaran perusahaan. Promosi yang bersifat informasi umumnya lebih sesuai dilakukan pada tahap-tahap awal di dalam siklus kehidupan produk.

4) Modifikasi tingkah laku

Kegiatan promosi ini berusaha merubah tingkah laku dan pendapat, dan memperkuat tingkah laku yang ada.

Tak jauh berbeda, Assauri S. (dalam Fitriana 2017:33-34) menjelaskan mengenai tujuan dari promosi penjualan yakni mengidentifikasi dan menarik konsumen baru, mengkomunikasikan produk baru, meningkatkan jumlah konsumen untuk produk yang telah dikenal secara luas, mengajak konsumen untuk mendatangi toko tempat penjualan produk, menginformasikan kepada konsumen tentang peningkatan kualitas produk, dan memotivasi konsumen agar membeli suatu produk.

c. Bauran Promosi

Secara garis besar bentuk promosi memiliki kesamaan, namun kesamaan tersebut dapat dibedakan berdasarkan spesifikasi tugasnya. Menurut Gitosudarmo (2014:285-288) terdapat 4 bentuk komunikasi pemasaran, yakni:

1) Periklanan (advertising)

Iklan merupakan alat utama bagi pengusaha untuk mempengaruhi konsumennya, periklanan dapat dilakukan melalui surat kabar, radio, majalah, bioskop, televisi, ataupun dalam bentuk posterposter yang dipasang di pinggir jalan ataupun tempat-tempat yang strategis lain.

2) Promosi penjualan (sales promotion)

Merupakan kegiatan untuk menjajakan produk yang dipasarkannya sedemikian rupa sehingga konsumen akan mudah untuk melihatnya dan bahkan dengan cara penempatan dan pengaturan tertentu maka produk tersebut akan menarik perhatian konsumen.

3) Publikasi (publication) 
Cara ini dilakukan dengan cara membuat berita tentang produk atau perusahaan tersebut di mass media masa, misalnya berita di surat kabar, berita di radio, atau televisi, majalah tertentu dan sebagainnya.

4) Penjualan personal (personal selling)

Merupakan kegiatan untuk melakukan kontak langsung dengan para calon konsumennya.

2. Minat Peserta Didik

a. Pengertian Minat Peserta Didik

Minat dalam kehidupan sehari-hari sebagaimana dapat dilihat di Kamus Besar Bahasa Indonesia (Depdiknas, 2002) diartikan sebagai kecenderungan hati yang tinggi terhadap sesuatu, gairah, perhatian, keinginan dan kesukaan. Menurut Slameto (dalam Eva, 126) menyatakan bahwa minat adalah suatu rasa lebih suka dan rasa keterikatan pada suatu hal atau aktivitas, tanpa ada yang menyuruh.

Menurut Rohmah dalam bukunya Psikologi pendidikan (2012) minat adalah penerimaan akan suatu hubungan antara diri sendiri dengan sesuatu diluar diri, semakin kuat hubungan tersebut maka minat semakin besar minat (dalam Eka 2017:24).

Sedangkan Eka (2017:25) mengartikan minat peserta didik baru sebagai suatu ketertarikan peserta didik/ orang tua terhadap suatu lembaga pendidikan tanpa adanya paksaan untuk mengembangkan potensi yang ada dalam dirinya sesuai dengan tahap perkembangannya.

Dari beberapa pengertian di atas dapat disumpulkan bahwa minat merupakan kecenderungan hati, ketertarikan, atau rasa suka, pada suatu hal untuk mengetahui, mempengaruhi, mempelajari suatu hal tanpa ada yang menyuruh.

b. Ciri-Ciri Minat

Terdapat beberapa ciri minat, menurut Harlock (dalam Al Khearunisa, 2012:13-17) bahwa ciri tersebut adalah sebagai berikut: 
1) Minat tumbuh bersamaan dengan perkembangan fisik dan mental Dalam perkembangannya minat juga bisa berubah. Perubahan ini terjadi selama perubahan fisik dan mental, contohnya perubahan minat karena perubahan usia.

2) Minat tergantung pada persiapan belajar

Kesiapan belajar merupakan salah satu penyebab meningkatnya minat seseorang. Seseorang tidak akan mempunyai minat sebelum mereka siap secara fisik maupun mental.

3) Minat bergantung pada kesempatan belajar

Kesempatan untuk belajar bergantung pada lingkungan dan minat, baik anak-anak maupun dewasa, yang menjadi bagian lingkungan anak. Karwna lingkungan anak kecil sebatas lingkungan rumah, maka minat mereka tumbuh dari rumah. Dengan bertambahnya lingkup sosial mereka menjadi tertarik pada minat orang diluar rumah yang mulai mereka kenal.

4) Perkembangan minat terbatas

Hal ini disebabkan oleh keadaan fisik yang tidak memungkinkan. Seseorang yang cacat fisik tidak memiliki minat yang sama seperti teman sebayanya yang keadaan fisiknya normal. Selain itu perkembangan minat juga dibatasi oleh pengalaman sosial yang sangat terbatas.

5) Minat dipengaruhi oleh budaya

Kemungkinan minat akan lemah jika tidak diberi kesempatan untuk menekuni minat yang dianggap tidak sesuai oleh kelompok atau budaya mereka.

6) Minat berbobot emosional

Minat berhubungan dengan perasaan, bila suatu objek dihayati sebagai sesuatu yang sangat berharga maka timbul perasaan senang yang pada akhirnya diminatinya. Bobot emosional menentukan kekuatan minat tersebut, bobot emosional yang tidak menyenangkan akan melemahkan minat dan sebaliknya, bobot yang menyenakngakn akan meningkatkan minatnya. 
7) Minat dan egosentris

Minat berbobot egosentris jika seseorang terhadap sesuatu baik manusia maupun barang mempunyai kecenderungan untuk memilikinya.

c. Fungsi Minat

Menurut Whiterington minat mempunyai fungsi yaitu dapat mengarahkan seseorang untuk mencapai tujuan hidup seseorang. Sedangkan menurut Abu Ahmadi (1997), minat juga dapat menjadi motivasi yang kuat bagi seseorang untuk berhubungan secara aktif (dalam Al Khaerunisa, 2012:18).

Minat mempunyai pengaruh yang besar terhadasp suatu pilihan, karena bila suatu pilihan tidak didasari oleh minat yang tinggi maka hal tersebut sama artinya dengan pilihan tersebut tidak memiliki daya tarik. Begitupun dalam menentukan pilihan atau keputusan terhadap suatu instansi pendidikan yang menjadi objek dari beberapa dilema pilihan tersebut.

d. Jenis-Jenis Minat

Menurut Dudu Abdullah yang dikutip oleh Suhartono (dalam Al Khaerunisa, 2012:20), minat jika dilihat dari segi timbulnya dibedakan menjadi dua macam:

1) Minat spontan yaitu minat yang timbul dengan sendirinya

Secara harfiah minat spontan merupakan minat yangtimbul tanpa danya perencanaan maupun kesengajaan, maupun pengarahan.

2) Minat disengaja yaitu minat yang timbul karena dibangkitkan Seseorang dapat dengan sengasja mengrahkan minatnya yaitu memusatkan perhatiannya, kemauannya, perasaan serta pikiran pada suatu obyek tertentu yang ada diluar dirinya

e. Indikator Minat

Menurut Ferdinand, (dalam Adji 2014:5) minat dapat diidentifikasikan melalui indikator-indikator sebagai berikut:

1) Minat transaksional yaitu kecenderungan seseorang untuk membeli produk. 
2) Minat refrensial yaitu kecenderungan seseorang untuk mereferensikan produk kepada orang lain.

3) Minat preferensial adalah minat yang menggambarkan perilaku seseorang yang memiliki preferensi utama pada produk tersebut. Preferensi ini hanya dapat diganti jika terjadi sesuatu dengan produk preferensinya.

4) Minat eksploratif adalah minat yang menggambarkan perilaku seseorang yang selalu mencari informasi mengenai produk yang diminatinya dan mencari informasi untuk mendukung sifat-sifat positif dari produk tersebut.

Sehingga dapat ditarik kesimpulan bahwa minat peserta didik merupakan suatu situasi kecenderungan peserta didik terhadap suatu lembaga pendidikan sehingga mempengaruhi tingkat keputusan pemilihan tanpa adanya paksaan.

3. Kajian terdahulu

1) Penelitian oleh Nuruna Hayatus Sa'adah (2018)_ Strategi Pengembangan Kinerja Marketing Pendidikan Melalui Human capital dan Social Kapital di MAN 3 Banyuwangi Tahun Pelajaran 2017/2018. Dengan jenis penelitian deskriptif kualitatif dengan kesimpulan 1) Strategi merketing pendidikan MAN 3 Banyuwangi memiliki beberapa langkah yaitu, mencari konsumen dan mengelolanya, mewujudkan ekspektasi menjadi nyata, mencari donasi dengan cara strategi substantif, bottom up, deregulatory, dan cooperative. 2) Tenaga pendidik yang linier dengan bidang masingmasing dan memiliki gedung ma'had putri sebagai faktor pendukung. Dan sarana prasanan yang kurang memadahi sebagai faktor penghambat.

2) Penelitian oleh Dewi Masruroh (2017) _ Marketing Pemndidikan di SDN Buluagung 6 Siliragung Banyuwangi tahun pelajaran 2016/2017. Dengan jenis penelitian deskriptif kualitatif dengan hasil temuan 1) Pelaksanaan mirror image sebagai marketing pendidikan di 
SDN 6 Buluagung dengan menggunakan promosi. 2) Pelaksanaan multi image sebagi marketing pendidikan di SDN 6 Buluagung melalui tanggapan masyrakat, tanggapan calon peserta didik, dan wali peserta didik, serta pemerintah yang berasumsi positif. 3) Pelaksanaan Current image sebagai marketing pendidikan di SDN 6 Buluagung berupa peran guru yang sesuai kapasitas, calon siswa yang sangat antusias, stretegi kepala sekolah dalam mempromosikan instansi, kegiatan kunjungan dan kegiatan keagamaan dalam usahanya mempromosikan dan memperkenalkan instansi.

3) Penelitian Afidatun Khasanah (2015) Pemasaran Jasa Pendidikan Sebagai Staretegi Peningkatan Mutu Di Sd Alam Baturraden. Dengan kesimpulan bahwa pendidikan merupakan investasi masa depan yang sangat urgen. Oleh karena itu sangat dibutuhkan adanya kualitas pendidikan dengan mutu yang baik pula. Melalui pemasaran pendidikan, peningkatan mutu dapat memberikan berbagai manfaat bagi lembaga pendidikan baik bagi konsumen pendidikan maupun income dan output lembaga pendidikan tersebut. Dalam pemasaran jasa pendidikan terdapat unsur-unsur yang sangat penting dan dapat dipadukan sedemikian rupa sehingga dapat menghasilkan strategi pemasaran yang dapat digunakan untuk memenangkan persaingan. Bauran pemasaran merupakan alat bagi pemasar yang terdiri atas berbagai unsur suatu program pemasaran yang perlu dipertimbangkan agar implementasi strategi pemasaran dan positioning yang ditetapkan dapat berjalan sukses. Bauran pemasaran terdiri dari 7P yaitu product, price, place, promotion, people, physical evidence dan process.

Dari ketiga penelitian terdahulu tersebut, dapat disimpulkan bahwa ketiga penelitian tersebut memiliki suatu kesamaan dengan penelitian yang penulis lakukan diantaranya adalah berangkat dari tema permasalahan yang sama yakni marketing pendidikan, hingga subjek penelitian yakni MAN 3 Banyuwangi. Namun, teori dan teknik analisis kuantitatif menjadikan teknik analisi penelitian yang peneliti lakukan berbeda dangan ketiga penelitian terdahulu tersebut. Sehingga tidak 
menutup kemungkinan penelitian yang penulis lakukan akan menghasilkan hasil dan kesimpulan penelitian yang berbeda.

\section{Metode Penelitian}

1. Jenis Penelitian ini deskriptif kuantitatif

2. Jumlah sampel yang digunakan dalam penelitian adalah 35 responden

3. Teknik Pengumpulan Data yang digunakan adalah observasi, angket dan dokumentasi

4. Validitas data menggunakan rumus korelasi product moment

5. Reabilitas data menggunakan rumus Alpha

6. Analisis data menggunakan rumus korelasi regresi sederhana

\section{Hasil Penelitian}

1) Uji Validitas

Data variabel Marketing Pendidikan melalui Strategi Promosi Uji validitas merupakan langkah untuk menguji apakah instrumen yang digunakan dapat mengukur apa yang seharusnya diukur atau tidak. Dalam hal ini uji validitas dilakukan dengan pengujian menggunakan rumus product moment. Yaitu dengan membandingkan $r_{\text {hitung }}$ dan $r_{\text {tabel }}$ Apabila $r_{\text {hitung }}$ lebih besar dari $r_{\text {tabel }}$, maka perbedaan yang ada adalah signifikan, sehingga instrumen dikatakan valid. Tingkat signifikan kepada uji $\mathrm{r}$ adalah 0,05 atau 5\% hasil uji validitas terhadap instrumen penelitian korelasi strategi promosi pendidikan dengan minat peserta didik baru dikatakan valid, karena $r_{\text {hitung }}$ lebih besar dari $r_{\text {tabel }}$.

Tabel 1

Validitas X

\begin{tabular}{|c|c|c|c|}
\hline No & Harga $\mathrm{R}_{\text {hitung }}$ & Harga $\mathrm{R}_{\text {tabel }}$ & Keputusan \\
\hline 1 & 0,598 & 2,042 & valid \\
\hline 2 & 0,650 & 2,042 & valid \\
\hline 3 & 0,627 & 2,042 & valid \\
\hline 4 & 0,579 & 2,042 & valid \\
\hline 5 & 0,480 & 2,042 & valid \\
\hline 6 & 0,414 & 2,042 & valid \\
\hline 7 & 0,513 & 2,042 & valid \\
\hline 8 & 0,650 & 2,042 & valid \\
\hline
\end{tabular}

Pengaruh Promosi Pendidikan Terhadap Minat Peserta Didik Baru MAN 3

Banyuwangi

Mahbub, Eva Husnia Zen 
Sumber : Olahan peneliti, 2019

Tabel 2

Validitas Y

\begin{tabular}{|c|c|c|c|}
\hline No & Harga $\mathrm{R}_{\text {hitung }}$ & Harga $\mathrm{R}_{\text {tabel }}$ & Keputusan \\
\hline 1 & 0.367 & 2,042 & valid \\
\hline 2 & 0.631 & 2,042 & valid \\
\hline 3 & 0.746 & 2,042 & valid \\
\hline 4 & 0.374 & 2,042 & valid \\
\hline 5 & 0.597 & 2,042 & valid \\
\hline 6 & 0.557 & 2,042 & valid \\
\hline 7 & 0.684 & 2,042 & valid \\
\hline 8 & 0.684 & 2,042 & valid \\
\hline
\end{tabular}

Sumber : Olahan peneliti, 2019

Berdasarkan data di atas diketahui bahwa semua pengujian terhadap instrumen variabel $\mathrm{X}$ dan $\mathrm{Y}$ menunjukkan bahwa seluruh pernyataan yang diajukan valid. Nilai $r_{\text {tabel }}$ untuk taraf signifikansi 0,05 atau 5\% dan $\mathrm{N}$ 35-2 = 33 adalah 2,042 dengan demikian semua pernyataan dalam kuesioner dapat dipercaya dan dapat digunakan untuk mengumpulkan data yang diperlukan.

2) Uji Reliabilitas

Suatu instrumen dikatakan reliabel apabila instrumen tersebut digunakan untuk mengukur gejala atau objek yang sama dari satu kali akan diperoleh hasil yang sama atau konstan. Pengujian reliabilitas dilakukan dengan menggunakan teknik Cronbach Alfa sehingga data dapat dikatakan reliabel jika nilai data variabel taraf signifikansinya di bawah 0,05 .

a) Data variabel Promosi pendidikan (X)

Menghitung reabilitas seluruh kuisioner menggunakan rumus Alpha

Cronbach:

$r_{a c}=\left\{\frac{k}{(k-1)}\right)\left\{1-\frac{\sum \sigma_{b}^{2}}{\sigma_{t}^{2}}\right\}$

$r_{a c}=\left\{\frac{8}{(8-1)}\right\}\left\{1-\frac{9.0808}{22.572}\right\}$

$r_{a c}=0,685$

Pengaruh Promosi Pendidikan Terhadap Minat Peserta Didik Baru MAN 3

Banyuwangi

Mahbub, Eva Husnia Zen 
Berdasarkan hasil perhitungan di atas, diketahui hasil $\mathrm{r}_{\mathrm{ac}}=0,685$. Instrumen dikatakan reliabel jika nilai $\mathbf{r}_{\mathrm{ac}}>0,5$ dan Instrumen dikatakan memiliki tingkat reliabilitas tinggi jika nilai $\mathbf{r}_{\mathbf{a c}}>0,6$. Dengan demikian semua pernyataan dalam kuesioner dinyatakan memiliki reliabilitas tinggi.

Hasil uji reliabilitas menggunakan SPSS versi 16.

Tabel 3

Hasil Reabilitas Alpha Cronbach

Reliability Statistics

\begin{tabular}{|r|c|}
\hline Cronbach's Alpha & N of Items \\
\hline
\end{tabular}

Sumber: Hasil pegolahan SPSS v.16

b) Data variabel minat peserta didik baru (Y)

Menghitung reabilitas seluruh kuisioner menggunakan rumus

Alpha Cronbach:

$r_{a c}=\left\{\frac{k}{(k-1)}\right\}\left\{1-\frac{\sum \sigma_{b}^{2}}{\sigma_{t}^{2}}\right\}$

$r_{a c}=\left\{\frac{8}{(8-1)}\right\}\left\{1-\frac{8.8342}{22.019}\right\}$

$r_{a c}=0,684$

Berdasarkan hasil perhitungan di atas, diketahui hasil $\mathrm{r}_{\text {ac }}=$ 0,684. Instrumen dikatakan reliabel jika nilai $\mathbf{r}_{\mathbf{a c}}>0,5$ dan Instrumen dikatakan memiliki tingkat reliabilitas tinggi jika nilai $\mathbf{r}_{\mathbf{a c}}>0,6$. Dengan demikian semua pernyataan dalam kuesioner dinyatakan memiliki reliabilitas tinggi.

Hasil uji reliabilitas menggunakan SPSS versi 16.

Tabel 4

Hasil Reabilitas Alpha Cronbach Reliability Statistics

\begin{tabular}{|c|c|}
\hline Cronbach's Alpha & $\mathrm{N}$ of Items \\
\hline .684 & $\varepsilon$ \\
\hline
\end{tabular}

Sumber: Hasil pegolahan SPSS v.16 
3) Uji Asumsi Klasik (Uji Normalitas Data)

Uji normalitas merupakan cara untuk menguji apakah variabelvariabel dalam sebuah model regresi mempunyai distribusi normal atau tidak. Pengujian dilakukan dengan menggunakan Kolmogrov Semirnov. Pengujian normalitas data sebagai berikut.

Tabel 4

\section{Hasil Uji Normalitas}

One-Sample Kolmogorov-Smirnov Test

\begin{tabular}{|c|c|c|c|}
\hline & & promosi & minat \\
\hline \multicolumn{2}{|l|}{$N$} & 35 & 35 \\
\hline \multirow[t]{2}{*}{ Normal Parameters $^{a}$} & Mean & 31.3143 & 29.2571 \\
\hline & Std. Deviation & 4.83110 & 4.76101 \\
\hline \multirow{3}{*}{$\begin{array}{l}\text { Most Extreme } \\
\text { Differences }\end{array}$} & Absolute & .121 & .129 \\
\hline & Positive & .121 & .129 \\
\hline & Negative & -.111 & -.076 \\
\hline \multicolumn{2}{|l|}{ Kolmogorov-Smirnov Z } & .719 & .761 \\
\hline \multicolumn{2}{|l|}{ Asymp. Sig. (2-tailed) } & .680 & .608 \\
\hline \multicolumn{2}{|c|}{ a. Test distribution is Normal. } & & \\
\hline
\end{tabular}

Sumber: Hasil pegolahan SPSS v.16

Dari tabel tersebut, dapat dilihat bahwa nilai taraf kesalahan sebesar 0,680 dan 0,608 yang berarti lebih besar dari 0,05. Dari hasil tersebut jika diinterpretasikan dengan kriteria pengujian yaitu jika nilai signifikansi > 0,05, maka data berdistribusi normal. Jadi dari hasil tersebut berarti nilai signifikansi $0,200>0,05$ yang berarti data berdistribusi normal.

4) Analisis Strategi Promosi Pendidikan dan Minat Peserta Didik Baru

Setelah melakukan perhitungan data angket variabel Budaya Organisasi (X) dan variabel Motivasi Kerja (Y) diperoleh data rekapitulasi angket pada tabel berikut: 
Tabel 5

Rekapitulasi Hasil Penelitian Tentang Strategi Promosi Pendidikan MAN 3

Banyuwangi

\begin{tabular}{|c|c|c|c|c|}
\hline No & Indikator & Skor & Presentase & Keputusan \\
\hline 1 & Periklanan & 245 & $70 \%$ & Kuat \\
\hline 2 & Penjualan perorangan & 283 & $80 \%$ & Kuat \\
\hline 3 & Promosi penjualan & 284 & $81 \%$ & Sangat baik \\
\hline 4 & Publikasi & 284 & $81 \%$ & Sangat baik \\
\hline & Jumlah & 1096 & $312 \%$ & \multirow[b]{2}{*}{ Kuat } \\
\hline & Rata Rata & 274 & $78,2 \%$ & \\
\hline
\end{tabular}

Sumber: Hasil olahan peneliti

Hasil penelitian ini menunjukkan bahwa tingkat persentase variabel Y yang berhasil dicapai adalah sebagai berikut:

$$
\begin{aligned}
\% & =\frac{n}{N} \times 100 \% \\
& =\frac{1096}{1400} \times 100 \% \\
& =78,2 \%
\end{aligned}
$$

Berdasarkan data di atas, tingkat persentase variabel $\mathrm{X}$ yang berhasil dicapai adalah sebesar $78,2 \%$. Jika dilihat pada tabel indeks konfirmasi nilai angket, maka nilai tersebut berada pada interval $61 \%$ sampai dengan $80 \%$ dengan kategori sangat kuat. Hal tersebut juga dilihat dari berbagai indikator strategi promosi, yaitu periklanan dengan persentase $70 \%$, penjualan perorangan $80 \%$, promosi penjuaan $81 \%$, dan publikasi $81 \%$, Masing-masing indikator memiliki persentase dengan interval $61 \%$ sampai $80 \%$ dan $81 \%$ sampai $100 \%$ Dengan demikian menunjukkan bahwa strategi prmosi pendidikan MAN 3 Banyuwangi tergolong kuat.

Tabel 6

Rekapitulasi Hasil Penelitian Tentang Minat Peserta Didik MAN 3 Banyuwangi

\begin{tabular}{|c|l|c|c|c|}
\hline No & \multicolumn{1}{|c|}{ Indikator } & Skor & Presentase & Keputusan \\
\hline 1 & Minat transaksional & 230 & $65 \%$ & Kuat \\
\hline 2 & Minat refrensial & 245 & $70 \%$ & Kuat \\
\hline 3 & Minat preferensial & 284 & $76 \%$ & Kuat \\
\hline 4 & Minat eksploratif & 284 & $80 \%$ & Kuat \\
\cline { 1 - 2 } \multicolumn{2}{r|}{ Jumlah } & 1043 & $312 \%$ & \multirow{2}{*}{ Kuat } \\
\cline { 1 - 3 } & Rata Rata & 260 & $74,5 \%$ & \\
\hline
\end{tabular}

Sumber: Hasil olahan peneliti

Pengaruh Promosi Pendidikan Terhadap Minat Peserta Didik Baru MAN 3

Banyuwangi

Mahbub, Eva Husnia Zen 
Hasil penelitian ini menunjukkan bahwa tingkat persentase variabel Y yang berhasil dicapai adalah sebagai berikut:

$$
\begin{aligned}
\% & =\frac{n}{N} \times 100 \% \\
& =\frac{1043}{1400} \times 100 \% \\
& =74,5 \%
\end{aligned}
$$

Berdasarkan data di atas, tingkat persentase variabel Y yang berhasil dicapai adalah sebesar 74,5\%. Jika dilihat pada tabel indeks konfirmasi nilai angket, maka nilai tersebut berada pada interval $61 \%$ sampai dengan $80 \%$ dengan kategori kuat. Hal tersebut juga dilihat dari beberapa indikator minat peserta didik baru, antara lain minat transaksional persentase $65 \%$, minat referensial $70 \%$, minat preferensial $76 \%$, dan minat eksploratif $80 \%$, Dengan demikian menunjukkan bahwa minat peserta didik baru MAN 3 Banyuwangi tergolong kuat.

a) Analisis strategi promosi pendidikan terhadap minat peserta didik baru

Analisis data yang digunakan dalam penelitian ini ialah uji regresi linier sederhana, Sebagaimana disampaikan pada bagian sebelumnya bahwa penelitian ini menggunakan satu variabel bebas atau satu prediktor. Untuk keperluan analisis digunakan teknik regresi linier sederhana dengan rumus $\mathrm{Y}=\mathrm{a}+\mathrm{bX}$.

Hasil di atas dibuktikan dengan hasil menggunakan SPSS:

\section{Tabel 7}

\begin{tabular}{|c|c|c|c|c|c|}
\hline \multirow[b]{2}{*}{ Model } & \multicolumn{2}{|c|}{ Unstandardized Coefficients } & \multirow{2}{*}{\begin{tabular}{|c|}
$\begin{array}{c}\text { Standar } \\
\text { dized } \\
\text { Coeffici } \\
\text { ents }\end{array}$ \\
Beta \\
\end{tabular}} & \multirow[b]{2}{*}{$\mathrm{t}$} & \multirow[b]{2}{*}{ Sig. } \\
\hline & $\mathrm{B}$ & Std. Error & & & \\
\hline (Constant) & 6,449 & 3,645 & & 1,769 & 086 \\
\hline promosi & ,709 &, 115 & ,731 & 6,163 &, 000 \\
\hline
\end{tabular}

\section{Hasil Analisis Regresi Linier}

Coefficients $^{\mathrm{a}}$

a. Dependent Variable: minat

Sumber : Hasil Output SPSS V.16

Berdasarkan hasil di atas, diperoleh hasil regresi yaitu $\mathrm{Y}=6,449$ $+0,709 X$.

a. $\mathrm{Y}=6,449+0,709 \mathrm{X}$.

Pengaruh Promosi Pendidikan Terhadap Minat Peserta Didik Baru MAN 3

Banyuwangi

Mahbub, Eva Husnia Zen 
$\mathrm{Y}=$ Startegi Promosi

$\mathrm{X}=$ Minat Peserta Didik

b. Atau strategi promosi $=6,449+0,709$ minat peserta didik

1) Konstanta sebesar 6,449 menyatakan bahwa jika tidak ada minat peserta didik, maka strategi promosi adalah 6,449

2) Koefisien regresi sebesar 0,709 menyatakan bahwa setiap penambahan (karena tanda positif (+)) 1 skor strategi promosi akan meningkatkan minat peserta didik sebesar 6,449 .

3) Untuk analisis regresi linier sederhana, harga koefisien korelasi $(0,731)$ adalah juga harga Standardized Coefficients (beta)

Sedangkan untuk mencari nilai rata-rata (mean) dari nilai $\mathrm{X}$ dan nilai Y menggunakan rumus sebagai berikut:

$$
\overline{\mathrm{Y}}=\frac{\sum Y}{N} \mathrm{X}=\frac{\sum X}{N}
$$

Hasil di atas dibuktikan dengan hasil menggunakan SPSS pada tabel Descriptive Statistic.

Tabel 8

\section{Descriptive Statistic}

Descriptive Statistics

\begin{tabular}{|l|r|r|r|}
\hline & Mean & Std. Deviation & \multicolumn{2}{|c|}{$\mathrm{N}$} \\
\hline minat & 28,6571 & 4,68378 & 35 \\
promosi & 31,3143 & 4,83110 & 35 \\
\hline
\end{tabular}

Sumber : Hasil Output SPSS V.16

Dari data tersebut diketahui bahwa;

1) Rata-rata (mean) variabel promosi dengan jumlah data (N) 35 subjek adalah 31,3143 dengan standar deviasi 4,83110.

2) Rata-rata (mean) variabel minat dengan jumlah data (N) 35 subjek adalah 28,6571 dengan standar deviasi 4,68378. 


\section{Tabel 9}

\section{Correlation}

\begin{tabular}{|ll|r|r|}
\hline \multicolumn{2}{c}{} & \multicolumn{2}{c|}{ Correlations } \\
\hline Pearson & minat & minat & promosi \\
Correlation & promosi & 1,000 &, 731 \\
& minat &, 731 & 1,000 \\
\hline Sig. (1- & .000 &, 000 \\
tailed) & promosi & 35 & 35 \\
\hline $\mathrm{N}$ & minat & 35 & 35 \\
& promosi & & \\
\hline
\end{tabular}

Sumber : Hasil Output SPSS V.16

Dari data korelasi tersebut diketahui bahwa:

1. Diperoleh besarnya korelasi 0,731 dengan signifikansi 0,000 . Karena signifikansi $<0,05$ maka Ho ditolak dan Ha diterima. Artinya ada hubungan yang signifikan antara strategi promosi pendidikan dengan minat peserta didik.

2. Berdasarkan harga koefisien yang positif yaitu 0,731 maka arah hubungannya adalah positif. Yang berarti semakin tinggi strategi promosi pendidikan semakin tinggi pula minat peserta didik.

5) Pengujian hipotesis

Analisis regresi memerlukan pengujian yang sesuai untuk memastikan keeratan hubungan dari variabel-variabel yang digunakan. Pengujian meliputi uji T dan Uji Korelasi dan Koefesien Determinasi.

a) Uji T

Uji T digunakan untuk mengetahui apakah strategi promosi pendidikan $(\mathrm{X})$ dan minat peserta didik baru $(\mathrm{Y})$ signifikan atau tidak. Kesimpulan dari uji $\mathrm{T}$ diperoleh dengan membandingkan $\mathrm{t}$ hitung dan $\mathrm{t}$ tabel dengan taraf signifikansi 0,05 atau 5\%. Kriteria pengambilan keputusannya adalah: 
1) Apabila t hitung $>\mathrm{t}$ tabel, maka Ho ditolak dan Ha diterima, yang artinya variabel bebas secara parsial memiliki pengaruh nyata dan signifikan terhadap variabel terikat.

2) Apabila thitung < t tabel, maka Ho diterima dan Ha ditolak, yang artinya variabel bebas secara parsial tidak memiliki pengaruh nyata dan tidak signifikan terhadap variabel terikat.

Hasil analisis uji t dalam penelitian ini disajikan dalam tabel berikut:

Tabel 10

Uji T

Coefficients $^{\mathrm{a}}$

\begin{tabular}{|c|c|c|c|c|c|c|}
\hline \multirow{2}{*}{\multicolumn{2}{|c|}{ Model }} & \multicolumn{2}{|c|}{ Unstandardized Coefficients } & $\begin{array}{c}\text { Standardiz } \\
\text { ed } \\
\text { Coefficient } \\
\text { s }\end{array}$ & \multirow[b]{2}{*}{$\mathrm{t}$} & \multirow[b]{2}{*}{ Sig. } \\
\hline & & $B$ & Std. Error & Beta & & \\
\hline \multirow[t]{2}{*}{1} & (Constant) & 6,449 & 3,645 & & 1,769 & 086 \\
\hline & promosi & ,709 & ,115 & ,731 & 6,163 & ,000 \\
\hline
\end{tabular}

a. Dependent Variable: minat

Sumber : Hasil Output SPSS V.16

Berdasarkan tabel analisis uji $\mathrm{t}$ dapat ditarik kesimpulan bahwa pada variabel budaya organisasi (X) t hitung yaitu 6,163 dibandingkan dengan $\mathrm{N}=35-2$ taraf signifikansi 5\% $=2,042$ menghasilkan hasil uji t hitung > t tabel, maka Ha diterima. Hal tersebut berarti bahwa variabel strategi promosi (X) yang ada di MAN 3 Banyuwangi tergolong tinggi.

b) Uji Korelasi dan Koefisien Determinasi

Sedangkan untuk mengetahui tentang besarnya pengaruh dari seluruh variabel independen (X) terhadap Variabel dependen (Y) maka menggunakan output regresi model Summary berikut: 


\section{Tabel 11}

Model Summary

Model Summary

\begin{tabular}{|l|r|r|r|r|}
\hline Model & $\mathrm{R}$ & $\mathrm{R}$ Square & Adjusted R Square & Std. Error of the Estimate \\
\hline 1 &, $731^{\mathrm{a}}$ &, 535 &, 521 & 3,24165 \\
\hline
\end{tabular}

a. Predictors: (Constant), promosi

b. Dependent Variable: minat

Sumber : Hasil Output SPSS V.16

Berdasarkan hasil dalam tabel di atas diketahui bahwa nilai korelasi ( $\mathrm{R}$ ) sebesar 0,731 dan koefisien determinasi ( $\mathrm{R}$ square) sebesar 0,535. Dengan demikian, dapat disimpulkan bahwa variabel bebas (X) budaya organisasi memiliki pengaruh sebesar 0,535 atau $53,5 \%$ variabel terikat (Y) motivasi kerja tenaga pendidik dan $42 \%$ dipengaruhi oleh faktor lain.

\section{E. Pembahasan}

\section{Promosi Pendidikan $(\mathrm{X})$}

Sesuai dengan yang diuraikan pada bagian sebelumnya bahwa permasalahan pertama dalam penelitian ini adalah bagaimana strategi promosi pendidikan MAN 3 Banyuwangi Tahun Pelajaran 2018/2019, maka hasil peneilitian ini menunjukkan bahwa pada hasil ananilis deskriptif prosentase menghasilkan prosentase hitung sebesar 78,2\% maka interpretasi berada pada $61 \%$ - $80 \%$ artinya strategi promosi pendidikan MAN 3 Banyuwangi berada dalam kategori kuat. Hal tersebut juga dilihat dari berbagai indikator strategi promosi, yaitu periklanan dengan persentase $70 \%$, penjualan perorangan $80 \%$, promosi penjuaan $81 \%$, dan publikasi $81 \%$, Masing-masing indikator memiliki persentase dengan interval $61 \%$ sampai $80 \%$ dan $81 \%$ sampai $100 \%$ Dengan demikian menunjukkan bahwa strategi prmosi pendidikan MAN 3 Banyuwangi tergolong kuat. 
2. Minat Peserta Didik Baru (Y)

Sesuai dengan yang diuraikan pada bagian sebelumnya bahwa permasalahan kedua dalam penelitian ini adalah bagaimana minat peserta didk baru MAN 3 Banyuwangi Thaun Pembelajaran 2018/2019, maka hasil penelitian ini menunjukkan bahwa pada hasil analisis deskriptif prosentase menghasilkan prosentase hitung sebesar 74,5\% maka interpretasi berada pada $61 \%$ - $80 \%$ artinya strategi minat peserta didik berada dalam kategori kuat. Hal tersebut juga dilihat dari beberapa indikator minat peserta didik baru, antara lain minat transaksional persentase $65 \%$, minat referensial $70 \%$, minat preferensial $76 \%$, dan minat eksploratif $80 \%$, Dengan demikian menunjukkan bahwa minat peserta didik baru MAN 3 Banyuwangi tergolong kuat.

3. Pengaruh Promosi Pendidikan (X) terhadap Minat Peserta Didik Baru (Y) Permasalahan ketiga yang ingin dijawab dalam penelitian ini adalah adakah pengaruh strategi promosi pendidikan terhadap minat peserta didik baru MAN 3 Banyuwangi Tahun Pembelajaran 2018/2019. Dari hasil penelitian menunjukkan bahwa ada terdapat pengaruh strategi promosi pendidikan terhadap minat peserta didik baru MAN 3 Banyuwangi Tahun Pembelajaran 2018/2019.

4. Seberapa Besar Pengaruh Promosi Pendidikan (X) terhadap Minat Peserta Didik Baru (Y)

Permasalahan keempat yang ingin dijawab dalam penelitian ini adalah seberapa besar pengaruh strategi promosi pendidikan terhadap minat peserta didik baru MAN 3 Banyuwangi Tahun Pembelajaran 2018/2019. Hasil penelitian ini menunjukkan bahwa strategi promosi pendidikan (X) memiliki pengaruh terhadap minat peserta didik baru (Y) sebesar 53,5\% dan sisanya 42,5\% dipengaruhi oleh variabel lain.

\section{F. Kesimpulan}

1. Promosi pendidikan MAN 3 Banyuwangi Tahun Pelajaran 2018/2019, maka hasil peneilitian ini menunjukkan bahwa pada hasil ananilis deskriptif prosentase menghasilkan prosentase hitung sebesar 78,2\% 
maka interpretasi berada pada $61 \%$ - $80 \%$ artinya strategi promosi pendidikan MAN 3 Banyuwangi berada dalam kategori kuat.

2. Minat peserta didk baru MAN 3 Banyuwangi Thaun Pembelajaran 2018/2019, hasil analisis deskriptif prosentase menghasilkan prosentase hitung sebesar $74,5 \%$ maka interpretasi berada pada $61 \%$ - $80 \%$ artinya strategi minat peserta didik berada dalam kategori kuat.

3. Pengaruh strategi promosi pendidikan terhadap minat peserta didik baru MAN 3 Banyuwangi Tahun Pembelajaran 2018/2019. Dari hasil penelitian menunjukkan bahwa ada terdapat pengaruh promosi pendidikan terhadap minat peserta didik baru MAN 3 Banyuwangi Tahun Pembelajaran 2018/2019.

4. Besar pengaruh strategi promosi pendidikan terhadap minat peserta didik baru MAN 3 Banyuwangi Tahun Pembelajaran 2018/2019. Hasil penelitian ini menunjukkan bahwa strategi promosi pendidikan (X) memiliki pengaruh terhadap minat peserta didik baru (Y) sebesar 53,5\% dan sisanya $42,5 \%$ dipengaruhi oleh variabel lain.

\section{G. Daftar Pustaka}

Adji, Jenifer., Hatane Samuel. 2014. Pengaruh Satisfaction dan Trust terhadap Minat Beli Konsumen (Purchase Intention) di Starbucks The Square Surabaya. Jurnal Manajemen Pemasaran Petra. 2(1): 1-10

Al Khaerunisa, Ayu. 2012. Meningkatkan Minat Belajar Siswa Dalam Membuat Hiasan Pada Busana (embroidery) Melalui Model Pembelajaran Kooperatif Tipe Numbered Head Together di SMK Karya Rini Yogyakarta. Skripsi

Amalia, Lili.2017. Strategi Pemasaran Jasa Pendidikan di SMP Harapan Baru Bekasi. Skripsi

Dewi, Chandra. 2014. Pengaruh Kualitas Pelayanan Terhadap Kepuasan dan Minat Beli Konsumen di Rumah Makan Boga-Bogi Surakarta. Jurnal Informatika. 1(2):53-64

Eka, Zakiyah Pratiwi. 2017. Pelaksanaan Strategi Pemasaran Sekolah dalam Menarik Minat Peserta Didik Baru. Surakarta: IAIN

Eva, Roida Flora Siagia. Pengaruh Minat Dan Kebiasaan Belajar Siswa Terhadap Prestasi Belajar Matematika. Jurnal Formatif. 2(2):122-131

Pengaruh Promosi Pendidikan Terhadap Minat Peserta Didik Baru MAN 3

Banyuwangi

Mahbub, Eva Husnia Zen 
Gitosudarmo, Indriyo. 2014. Manajemen Pemasaran. Yogyakarta:BPFE

Herdiana, Nana Abdurrahman. 2015. Manajemen Strategi Pemasaran. Bandung: CV Pustaka Setia

Kotler, Philip. 2005. Manajemen Pemasaran. Jakarta:Indeks

Muhid, Abdul. 2012. Analisis Statistik. Sidoarjo: Zifatama Publishing

Shinta, Agustina. 2011. Manajemen Pemasaran. Malang: UB Press

Sugiyono. 2015. Metode Penelitian. Bandung: Alfabeta 